tant about the last patient is that if he had died the coroner would almost certainly have had had to bring in the death as being due to combined drugs, with both the mother and doctor denying that he had more than ordinary doses of sedatives. After recovery he was safely given the combined antidepressant drugs for a fortnight.-I am, etc.,

William Sargant Department of Psychological Medicine, St. Thomas's Hospital,

London S.E.1

1 Sargant, W. W., British Medical fournal, 1969, 2, 49.
2 Sargant, W. W., British Medical foumal, 1969,
3,118.

Fatal Septicaemia due to Yersinia Pseudotuberculosis

SIR,-The usual presentation of Yersinia pseudotuberculosis (Pasteurella) infection in man is most frequently manifested as mesenteric lymphadenitis. It occurs in children and boys are mainly affected. The infection occurs in many European countries including Poland. ${ }^{15}$ The diagnosis of Yersinia pseudotuberculosis infection is made on isolating the causative agent from the blood or lymph nodes. Serological and histopathological examinations are also of great importance. It is usually a benign infection, but fatal cases have been reported rarely. 4

Our patient was a 12-month-old girl admitted to the hospital on 19 December 1969. She was febrile with a temperature of $39.8^{\circ} \mathrm{C}$., and had a fine macular red rash and numerous petechiae on the skin of the face, trunk, and upper and lower limbs. The child was unconscious; she had irregular breathing with breaks of apnoea, a rapid arrhythmia of over $200 / \mathrm{min}$ with faint sounds; liver enlarged around $4 \mathrm{~cm}$, and the spleen was palpable beneath the left costal margin. Investigations showed protein in the cerebrospinal fluid $24 \mathrm{mg} / 100 \mathrm{ml}$ and W.B.C. $10,050 / \mathrm{mm}^{3}$.

On the basis of the clinical picture acute insufficiency of the suprarenal glands was diagnosed, due to septicaemia of unknown aetiology. Despite intensive care, including controlled respiration, circulation-stimulating drugs, cardiovascular stimulants, and high doses of hydrocortisone the patient died 45 minutes after admission, with symptoms of circulatory and respiratory failure. Only a few hours had elapsed between the onset of the first symptoms and death.

At necropsy blood and specimens of the intestine, lymph nodes, and spleen were delivered to the department of microbiology of the medical school in Bialystok for bacteriological examination. Gram-negative rods were isolated from the blood that we identified on the basis of their biochemical reactions as well as antigenic structure as being Yersinia pseudotuberculosis type I. The micro-organisms also in other features did not differ from the standard Yersinia pseudotuberculosis 'strains; the bacilli produced flagella and were motile only while incubated at $22^{\circ} \mathrm{C}$.

Histopathological diagnoses were: acute haemorrhagic colitis; acute mesenteric lymphadenitis; haemorrhagic and necrotic foci in the suprarenals; degeneration of the renal parenchyma, of the liver, and of the myocardium. Definitive diagnosis: fulminating septicaemia.
On the basis of the data obtained, mainly on the isolation of Yersinia pseudotuber culosis from the blood taken at necropsy, the diagnosis of fatal septicaemia from this microorganism can be made.

We have found that hens were probably the source of infection in this child. The girl lived in the country, and in the sera of hens belonging to her parents we found a high level of antibodies against Yersinia pseudotuberculosis type I.

This fatal case of septicemia due to Yersinia pseudotuberculosis is the only one thus far described in Poland and is therefore of special interest. Few similar cases have been described in the literature so far.-We are, etc.,

JERZY BOROWSKI MARIA L. ZAREMB LARYSA WASILUK

Department of Microbiology of the
Medical School in Bialystok,

and Province Olsztyn Hospital for Children,

Borowski, J., Kupryanow-Wolfart, K., Kurasz, S. and Sokolewic

Brown, G. W.; Brown, J. M., and Leditschke, J. F. Medical fournal of Australia. 1966, 1, 585 , 1961, 2. 997 .

England Fournal of Medicine. $1958,259,776$

Mollaret, H. H., et al., Presse Médicale, 1964,
72, 2671.

\section{Bacillaemia in Leprosy}

SIR,-It was interesting to read the suggestion by Dr. A. B. A. Karat and others (6 February, p. 307) that bacillaemia occurs in all forms of leprosy. Rhodes-Jones demonstrated bacillaemia in both tuberculoid and lepromatous leprosy, while John Lowe $^{2}$ and Iyengar $^{3}$ have also reported bacillaemia. The fact that this occurs deserves wider recognition.-I am, etc.,

Welwyn Garden City,

JOHN GARROD

1 Rhodes-Jones, R., Leprosy Review, 1963, 34, 26.

3 Iyengar, K. R. K., Indian fournal of Medical
Research, 1919, 7, 235 .

Jaundice after Treatment of Leukaemia with Busulphan

SiR,-We wish to report the terminal occur rence of cholestatic jaundice in a patient with acute relapse of chronic granulocytic leukaemia who had been treated with busulphan for more than six years. We have failed to find a similar in'stance of cholesta tic jaundice attributable to busulphan recorded in the literature.

An engineer aged 25 years presented on October 1963 having been "off colour" for two years. In the last six months he had gradually lost weight and noted occasional discomfort under the left ribs. Pallor of skin and mucosae and firm splenomegaly reaching $4 \mathrm{~cm}$ below the costal margin were found. Relevant laboratorv results were: $\mathrm{Hb}$ $9.1 \mathrm{~g} / 100 \mathrm{ml}$; total W.B.C. $205,000 / \mathrm{mm}^{3}$ (promyelocytes $6 \%$, myelocvtes $20 \%$, band cells $44 \%$, polymorphs $28 \%$, eosinophils $2 \%$ ); platelets $155,000 / \mathrm{mm}^{3}$, bone marrowsmears consistent with chronic granulocytic leukaemia; leucocyte alkaline phosphatase score $12 ; \mathrm{Ph}^{1}$-chromosome positive.
He progressed satisfactorily on continuous treatment with busulphan, the dosage varying between $4 \mathrm{mg}$ daily and $0.5 \mathrm{mg}$ every third day, until 2 December 1969 when coryza had developed. Two weeks later the spleen was enlarging and the haemoglobin level had fallen to $10.3 \mathrm{~g} / 100 \mathrm{ml}$ from previously normal levels. The leucocyte count was $25,000 \mathrm{~mm}^{3}$ with no blast cells and the platelet count was 100,000 $\mathrm{mm}^{3}$. At this tinıe nausea, occasional vomiting, mild intermittent fever, and backache developed, also icterus. The direct van den Bergh reaction was positive, serum bilirubin was $2.3 \mathrm{mg} / 100$ $\mathrm{ml}$ and serum alkaline phosphatase level 38 K.A. units with normal thymol turbidity and flocculation. Examination of the urine showed trace of bilirubin with slight excess of urobilin and moderate excess of urobilinogen. The stool were paler than normal. Progressive fall in haemoglobin level to $4.7 \mathrm{~g} / 100 \mathrm{ml}$, rising total leucocyte count to $55,000 / \mathrm{mm}^{3}$ with $24 \%$ blast cells, falling platelet count to less than $10,000 / \mathrm{mm}^{3}$, a rising serum bilirubin up to 8 $\mathrm{mg} / 100 \mathrm{ml}$, along with slightly increased levels of transaminases (SGOT $52 \mathrm{~m} \mathrm{I.U./ml,} \mathrm{SGPT}$ $32 \mathrm{mIU} / \mathrm{ml}$ ) occurred during the next few days, together with rapid increase in splenomegaly. Despite supportive and "specific" therapy the patient died on 5 January 1970.

The total dose of busulphan was $4.075 \mathrm{~g}$ of which $0.7635 \mathrm{~g}$ was given in the 12 months preceding the onset of jaundice as compared with an annual average of $0.6623 \mathrm{~g}$ busulphan during the previous five years. The only other medicaments at the time of onset of icterus and for two years before this were ferrous fumarate and occasional sodium amytal at night. Necropsy revealed icterus and scattered petechiae. The enlarged and focally infarcted spleen showed diffuse infiltration by primitive granulocytic cells. The soft enlarged liver showed a very striking degree of centrilobular cholestasis while in other areas there was some swelling of liver cells. A portal tract infiltrate of variable intensity consisting of lymphocytes and plasma cells was noted and a few primitive granulocytic cells were seen scattered throughout the liver lobules. There was no evidence of extrahepatic biliary obstruction or gall bladder disease, and the degree of leukaemic infiltration of the liver was minimal. Vertebral bone marrow was cellular with aggregates of granulocytic precursors.

Toxic effects from busulphan are relatively rare. Pancytopenia is the main danger with excessive therapy, thrombocytopenia being the usual warning. Other toxic effects with prolonged therapy include melanotic pigmentation of the skin and very rarely, interstitial pulmonary fibrosis, a syndrome resembling adrenocortical insufficiency but in which a specific endocrine defect has not been demonstrated, atrophic bronchitis, glossitis, anhydrosis, alopecia totalis, impotence, sterility, and cataracts along with nuclear abnormal:ties in many other cells. ${ }^{1}$ Amenorrhoea and mild gynaecomastia ${ }^{2}$ and renal failure due to hyperuricaemia ${ }^{3}$ have also been noted.

The histological appearances of the liver strongly favour drug-induced cholestasis of hypersensitive type. The absence of an cosinophilic infiltrate in the liver that frequently accompanies this form of liver toxicity can be accounted for by the lack of circulating eosinophils during the terminal illness. Cholestatic jaundice in severe bacterial infections, with histology similar to that seen in this case has been described. ${ }^{4}$ However, there was no evidence either clinically or at necropsy to suggest severe infection of any form. It could also be argued the cholestasis was related to acute relapse of the chronic leukaemia, but this view has no histological suppori 
This hepatotoxic effect of busulphan therapy appears to be rare and in this case was associated with prolonged therapy. However, we suggest that jaundice in patients under treatment for chronic granulocytic leukaemia may be attributable to busulphan therapy rather than severe leukaemic infiltration of the liver.-We are, etc.,

\section{J. C. E. UNDERWOOD}

R. T. SHaHaNi

E. K. BLACKBURN

University Departments of Pathology

and Haematology,

Royal Infirmary, Sheffield

1 Wintrobe, M. M., Clinical Hematology 6th edn. 2 Galton, London, Kimpton, p. 1060 Galton, D. A. G.. Till, M.: and Wiltshaw, E.,
Annals of the New York Academy of Sciences.

3 Havhoe, F. G. J., and Kok, D'A., British Medical Fournal, 1957, 2.1468. enterology, 1964, 47, 590 .

\section{Aerosols in Asthma}

SIR,-We feel that the paper by Dr. L. H. Harris (5 December, p. 579) on the effects of isoprenaline plus phenvlephrine given by pressurized aerosol requires comment. The final sentence of the summary is misleading. On the test dav onlv 13 of the 2.3 natients showed any significant bronchodilatation, which does not support the statement that the combination aerosol has a satisfactory bronchodilator effect. This relative ineffectiveness of the combination aerosol as a bronchodilator has also been found bv Pflug et al.1 In their study Medihaler-duo was given to 13 patients with chronic airway obstruction, and in six of these there was either no change or an actual fall in FEV Recent pharmacological studies (Simonsson, B. G., personal communication; Price, F. J., personal communication) have demonstrated that there mav be alpha receptors in human bronchial muscle. Thus the addition of an alpha stimulant, phenylephrine, to an isoprenaline aerosol may well reduce its effectiveness as a bronchodilator.

Dr. Harris also claims in the summary of his paper that the aerosol is, "additionally safe if used by a severely hypoxic patient unaware of the seriousness of his condition." We believe that there is no aerosol that can be safely used by such a patient, if one defines safety in terms of avoiding a fall in arterial oxvgen tension. It is of interest that in Dr. Harris's series of the three patients with the lowest oxygen tensions there was a slight fall in arterial oxvgen tension in two of the subjects following Medihaler-duo. In addition, in the study previously quoted, by Pflug et al., 1 nine out of the 13 patients showed a fall in arterial oxygen tension, following inhalation of Medihaler-duo and in five of these the fall was greater than $5 \mathrm{~mm} \mathrm{Hg}$.

We would not agree that a comparative trial with isoprenaline was unnecessary. We think that the effects of isoprenaline, and isoprenaline plus phenylephrine, should be compared in the same patients. All of the previous studies auoted for isoprenaline except that of Waddell et al. ${ }^{2}$ were done either with wet aerosol isoprenaline (estimated doses being much higher than that contained in Medihaler-duo) or with intravenous isoprenaline. The study of Waddell et al. is the only study in which isoprenaline was administered by a pressurized aerosol and we would estimate that oxygen tension fell by more than $5 \mathrm{~mm}$ $\mathrm{Hg}$ in only one out of 12 patients, and this would not be statistically different from the results that the author reports with Medihaler-duo. Similarly, under the results quoted for orciprenaline, two of the studies were performed with subcutaneous orciprenaline and one with a wet aerosol of orciprenaline, and only the study of Meisner and Hugh-Jones ${ }^{3}$ looked at the effects of a pressurized aerosol of orciprenaline, and in this study no patient showed a fall in arterial oxygen tension. Thus the grouping together of several papers to obtain average changes is really quite unjustified in view of the differences in diagnoses, doses of drug administered, route of drug administration, time of sampling of arterial blood, and degree of hypoxaemia in the different patients.

We would once again emphasize the danger of suggesting that any aerosol is safe in severely hypoxic patients. There is still no scientific evidence to suggest that any available bronchodilator aerosol has an additional margin of safety as regards changes in arterial oxygen tension. We would make a plea for future studies on this important topic to be carried out in a properly controlled manner, and in particular against the use of such data in advertising material.We are, etc.,

Brompton Hospital,

J. W. Paterson Tim Clark

Brompton H.W.
London S.W.

1 Pflug, A. E., Cheney, F. W., and Butler J., American Review of Respiratory Diseases, Waddell, J. A., Emerson, P. A., and Gunstone, 3 Meisner, P., and Hugh-Jones, P., British Medical fournal, 1968, 1, 470 .

\section{Practolol in Angina}

SIR,-I wish to report briefly a double-blind trial of practolol (Eraldin) in angina pectoris. Practolol is a beta-receptor antagonist which is cardioselective and is therefore preferable to other beta-blockers in patients with obstructive airways disease. It lacks the "quinidine-like" or membrane-stabilizing action of propranolol, it has intrinsic sympathomimetic activity, and is less liable than other beta-blockers to produce or exacerbate cardiac failure. Results of controlled trials of practolol in angina have varied, suggesting that it is less effective in relieving angina than propranolol. George, Nagle, and Pentecost ${ }^{1}$ found practolol almost as effective as propranolol, while Prichard, Lionel, and Richardson ${ }^{2}$ demonistrated only slight relief of angina by practolol in oral doses up to $2.4 \mathrm{~g}$ daily. Westerlund ${ }^{3}$ found no reduction in the number of anginal attacks although there was improvement in the work performance with exercise tests. In addition, Atkins, Blomqvist, and Cohen ${ }^{4}$ have found recently that practolol was more effective than propranolol in improving exercise tolerance measured by bicycle ergometry.

Twenty-eight patients with stable angina pectoris which had been present for a minimum of 3 months (mean 3 years 8 months) were studied. These were 20 men and 8 women, with mean age of 59.5 years. The trial started with a run-in period of one to three months, during which the dose of practolol was increased until subjective improvement of angina occurred. No patient was rejected owing to lack of improvement in this open part of the trial. The patients then entered the double-blind phase of the trial, consisting of two four-week periods in which they took either practolol or placebo in random order, later crossing over to the alternative preparation. The dose of practolol was that established in the open trial (range 200-800 mg/day, average 447 $\mathrm{mg}$ ). Patients were seen at fortnightly intervals throughout the trial and the frequency and severity of angina, trinitrin consumption, and effort tolerance were recorded. A summary of the patient preferences in the 28 natients follows:

Better in practolol period

Better in placebo period

Improved in both periods

3 Side effects were not troublesome. One patient, who was worse in both periods, could not take more than $200 \mathrm{mg}$ practolol daily because of nausea.

These natient preferences-10 improved on practolol compared to three improved in control periods-are statistically significant at the $5 \%$ level. The order of the practolol and control periods did not influence drug preference. The large number of patients improving in both periods, 12 out of 28 , may well be a feature of trials of effective drugs in angina, and is not seen in trials of inert drugs. ${ }^{5}$ The run-in period on practolol might well produce an improvement in exercise tolerance with improvement of cardiovascular reserve by increased exercise, which might persist into the control period.

I am most grateful to Dr. B. Nebenzahl, Dr. R. B. Royds, and Dr. R. A. Wiseman for help with this trial.

-I am, etc.

St. Albans City Hospital,

D. N. PHeAR

St. Albans, Herts

1 George, C. F. Nagle, R. E., and Pentecost, B. L., British Medical fournal, 1970, 2, 402. Richard, B. N. C., Lionel, N. D. W W and
Richardson. G. A. Postgraduate Medical fournal Suppl. 1971, Postgraduate Medical fournal Suppl. $1971,47,64$.

Atkins, J.' M., Blomqvist. C. G.. and Cohen, S., Circulation, 1970, Phear, D. N., British Medical fournal, 1968, 2, 740.

\section{Long-acting Phenothiazines}

SIR,-We would like to compliment you on your concise leading article on long-acting phenothiazines in schizophrenia (23 Januarv, p. 189). The effect on hospital admission rates is demonstrated by our retrospective study of 212 chronic schizophrenic outpatients attending St. Clement's Hospital in which each patient was acting as his own control. A total of 103 patients fulfilled the criteria of this study, in that they had a follow up period of 12 months or more and a previous history of fully documented hospital admissions prior to receiving injections of longacting fluphenazine. The remaining patients were excluded because they had received their injections for less than 12 months or had incomplete records. The number and duration of hospital admissions in the follow up period was compared with the number 